NASZA DERMATOLOGIA Online OUR DERMATOLOGY Online

Source of Support: Kirkuk Health Authority Competing Interests: None

\section{ASSOCIATION BETWEEN HERPES SIMPLEX VIRUS TYPE 2 (HSV 2) AND BAD OBSTETRIC OUTCOMES}

\author{
Hala Mohamed Majeed Hassan ${ }^{1,2}$, \\ Abdulghani Mohamed Alsamarai ${ }^{3,4}$, \\ Zainab Khalil Mohamed Aljumaili ${ }^{5}$, Firah Ghali Alsalihi ${ }^{6}$ \\ ${ }^{1}$ Department of Microbiology, Tikrit University College of Science, Tikrit, Iraq \\ ${ }^{2}$ College of Veterinary Medicine, University of Baghdad, Baghdad, Iraq \\ ${ }^{3}$ Departments of Medicine and Microbiology, Tikrit University College of Medicine, \\ Tikrit, Iraq \\ ${ }^{4}$ Asthma, Allergy Centre, Tikrit Teaching Hospital, Tikrit, Iraq \\ ${ }^{5}$ Department of Microbiology, Tikrit University College of Medicine, Kirkuk Health \\ Authority, Tikrit, Iraq \\ ${ }^{6}$ Department of Biochemistry, Tikrit University College of Women, Tikrit, Iraq
}

Corresponding author: Prof. Abdulghani Alsamarai galsamarrai@hotmail.com

Date of submission: 04.10.2013 / acceptance: 05.12.2013

\begin{abstract}
Introduction: HSV is a common human pathogen that lead to lifelong latent infection. Maternal infections may be associate with transmission to the fetus. The risk factors associated with HSV 2 seropositivity in pregnant women in Iraq are not well studied.

Aim: The present study conducted to verify the prevalence of HSV 2 infections in women with bad obstetric history (BOH) in Kirkuk Governorate.

Material and Methods: HSV 2 seropositivity among women aged 14 to 48 years was investigated by determination of HSV 2 IgG and IgM in a prospective, case control descriptive study.

Results: The overall HSV 2 seroprevalence was $29.9 \%$, with a non significant difference between women with BOH and women with normal pregnancy. HSV $2 \mathrm{IgM}$, as an indicator of current infection was demonstrated in $2 \%$ of the studied population, and was significantly ( $\mathrm{P}=0.002)$ higher in women with BOH compared to women with normal pregnancy. Both HSV 2 IgG and IgM were significantly varied with age groups, with trends of increasing with older ages. HSV $2 \operatorname{IgG}$ was statistically significantly higher in working women $(\mathrm{P}=0.03)$ as compared to housewife.

Conclusions: Significant association was found between HSV 2 seroprevalence and education levels, residence, smoking and animal exposure. Presence of pregnancy in women with HSV-2 latent infection was a risk factor for development of BOH.
\end{abstract}

Key words: TORCH; HSV; BOH, IgM; IgG; Kirkuk; Iraq

Cite this article:

Hala Mohamed Majeed Hassan, Abdulghani Mohamed Alsamarai, Zainab Khalil Mohamed Aljumaili, Firah Ghali Alsalihi. Association between Herpes Simplex virus type 2 (HSV 2) and bad obstetric outcomes. Our Dermatol Online. 2014; 5(1): 19-28.

\section{Introduction}

Viral infections accounts for major part of maternal infections which was responsible of the unfavorable outcome of pregnancy, mainly rubella, cytomegalovirus (CMV) and Herpes Simplex Virus (HSV) infections [1]. Genital herpes simplex viral infection is one of the most common sexually transmitted diseases [2].

Herpes simplex virus (HSV) infections are caused by two strains, HSV-1 and HSV-2. Orolabial infection is mainly caused by HSV-1, however, this strain is responsible for up to $53 \%$ of primary genital herpetic infection [3]. HSV-2 genital infection is much more likely to recur than genital HSV-1 infection, thus the presence of antibody to HSV-2 and a compatible clinical history would be strong presumptive evidence that the disease is recurrent genital herpes [4-6]. In addition to agent factor, genetic may play a role in susceptibility to HSV infection [7]. Primary genital HSV-1 or HSV-2 infection in pregnant women can result in abortion, premature labor and congenital and neonatal herpes [8-10]. HSV-2 infections in the newborn are particularly severe and can involve the CNS [11]. 
Recent changes in HSV-1 and HSV-2 infection epidemiology have been reported, with type incidence changes and sequential genital infections with HSV-1 and HSV-2 [12,13]. Little is known about the risk factors associated with HSV seropositivity in pregnant Iraqi women [14-17]. Identification of the risk factors may help to improve the control measures of HSV infection. Although there is improve in the diagnosis and treatment of TORCH infections, still it represent a problem in developing countries [18]. Clinical diagnosis of TORCH is difficult, since most of the maternal infections with adverse outcomes are initially asymptomatic. Routine TORCH complex screening during pregnancy is not recommended in Iraq and the extent to which it is performed is unknown. Using healthcare database, seroprevalence of TORCH complex was determined among women with bad obstetric history (BOH) $[18,19]$.

Only four studies reported concerning seroprevalence of HSV 2 in Iraqi women with bad obstetric history [14-17]. These four studies reported a wide range of HSV 2 seropositivity (with range from $5.8 \%$ to 73.9 for $\operatorname{IgM}$ ), while other study for Iraq, reported seroprevalence of $28.9 \%$ HSV 2 IgM in pregnant women [20]. In addition, the study population of the 3 studies ranged from 100 to 162 subjects, which is lower than sample size required for HSV 2 seroprevalence study. Recently, Zainab et al [15] in a large study population, reported a HSV-2 IgM seroprevalence of $5.8 \%$ in women with $\mathrm{BOH}$ in Kirkuk, Iraq. In addition, only two studies reported Seroprevalen of HSV-2 in Iraqi women with $\mathrm{BOH}$, their rate was $60.6 \%$ [14] and $34.5 \%$ [15]. Furthermore, the studies performed in Arab countries reported a range of $0.5 \%$ [21] to $7.6 \%$ [22] for HSV2 IgM and $6.5 \%$ [21] to $27.1 \%$ [23] for HSV2 IgG in pregnant women.

The literature review [19] highlights a gap in existing knowledge on the epidemiology and impact of maternal infection, especially on the aetiology of infectious agents that lead to puerperal sepsis and subsequent mortality. Increased surveillance and diagnostic capabilities in healthcare facilities and in the community is needed to identify the aetiological agents responsible for puerperal sepsis and maternal mortality [15]. The prevalence of maternal infection reported by the studies identified in literature regarding HSV 2 may be an underestimate of actual rates of infection as not all pregnant women in Iraq may have access to or choose to access formalized antenatal care. This could be due to financial constraints, difficulties in accessing these facilities, personal or cultural beliefs and interest of health professional education and research institutions. In addition, antenatal care services may not have the capacity to routinely screen for maternal infections, especially those that are asymptomatic and those that require serological tests such as PCR and ELISA to diagnose, due to limited resources or expertise. These infrastructural problems are essential contributors to the persistence of high maternal morbidity and mortality in developing countries and need to be overcome in order to accurately characterize the burden of maternal infections in these countries, including Iraq [19].

This literature review highlights the high microbial maternal infection rates in the developing world, including Iraq. Urgent, concerted action is required to reduce the burden of these infections. In addition to raising awareness about the severity of the problem of maternal infections in Iraq, data from seroepidemiological research will be beneficial in guiding public health policy, research interests and donor funding towards achieving improvement in health care delivery [19]. The aim of this study was to identify seroprevalence of HSV 2 IgG and $\operatorname{IgM}$ in women with bad obstetric history compared to those with normal pregnancy and the association of these markers with socio-demographic variables of Iraqi population in Kirkuk Governorate.

\section{Patients and Methods \\ Study Design and Settings}

The study design is a Descriptive Case Control Study and was performed in Kirkuk General Hospital. The study proposal was approved by Tikrit University College of Science ethical committee and Kirkuk Health Authority Research Committee. Informed consent taken from each women included in the study.

\section{Study Population}

The study population is women with childbearing age. Study population was recruited from Kirkuk General Hospital. A 838 women with age range from 14 to 48 were included in the study. Of the total, 547 women were with bad obstetric history (BOH) and 291 women with normal previous pregnancy as control group. The demographic information of these groups are shown in Table I. For serological analysis, $5-10 \mathrm{~mL}$ of venous blood was collected in a sterile container with strict aseptic precautions from each study subject. The serum was separated and stored in numbered aliquots at $-20 \mathrm{oC}$ till assayed. All the serum samples collected from the study and control groups were tested for HSV $2 \mathrm{IgM}$ and IgG antibodies by commercially- available (ELISA) kits. The results read by a Microwell reader and compared in a parallel manner with controls; optical density read at $450 \mathrm{~nm}$ on an ELISA reader.

\section{Collection of data}

All recruited women were subject for clinical examination and laboratory investigations were carried out for the study subjects to exclude other causes of foetal wastage, such as hypertension, diabetes mellitus, syphilis, Rh (rhesus) incompatibility, physical causes of abortion, and consanguinity. Subjects with known causes of foetal wastage were excluded from the study. All of them were interviewed to ascertain age, medical and obstetric information.

\begin{tabular}{|l|l|l|l|}
\hline \multicolumn{2}{|l|}{ Group } & \multicolumn{1}{c|}{ Number } & Mean age \pm SD in years \\
\hline \multirow{2}{*}{$\begin{array}{l}\text { Women with bad } \\
\text { obstetric history }\end{array}$} & Pregnant & 292 & $28.35 \pm 7.25$ \\
\cline { 2 - 4 } & Non pregnant & 255 & $28.24 \pm 6.81$ \\
\cline { 2 - 4 } & Total & 547 & \\
\hline \multirow{2}{*}{$\begin{array}{l}\text { Women with } \\
\text { normal pregnancy }\end{array}$} & Pregnant & 140 & $27.40 \pm 6.24$ \\
\cline { 2 - 4 } & Non pregnant & 151 & $28.06 \pm 10.51$ \\
\cline { 2 - 4 } & Total & 291 & \\
\hline Grand total & ANOVA & 838 & \\
\hline P value & \multicolumn{2}{|c}{ NS } & \\
\hline
\end{tabular}




\section{Determination of HSV-2 IgM and IgG}

ELISA was used for determination of $\operatorname{IgM}$ and $\operatorname{IgG}$ for HSV-2 and the test was performed according to manufacturer instructions. The kit purchased from BioCheck, Inc, 323 Vintage Park Dr, Foster City, CA 94404.

\section{Statistical Analysis}

The proportion and the mean value were computed in appropriate situations. To find out any association between categorical data, Chi square test was employed using the SPSS (Version 16). If the sample size in $\mathrm{BOH}$ group not reach the targeted number Power Analysis were performed to determine the accuracy of findings. The study finding data were presented as frequency \pm SD and 95\% Confidence Interval. The determinants for HSV 2 infection is determined by calculation of Odd Ratio. Chi square used to determine the significance of differences between the groups.

\section{Results}

A total of 838 women were recruited to study, of them 547 were with $\mathrm{BOH}$ and 291 were with normal previous pregnancy. The demographic of the study population included in the statistical analysis was as shown in Table I. There was no significant differences in mean of age between the study groups.
The overall HSV 2 seroprevalence in our study population was $29.9 \%$, with a non significant $\left(\mathrm{X}^{2}=0.59, \mathrm{P}=>0.05\right)$ difference between women with $\mathrm{BOH}(29.1 \%)$ and women with normal pregnancy $(31.6 \%)$. However, there was significant difference between pregnant and non pregnant women in $\mathrm{BOH}\left(\mathrm{X}^{2}=10.45\right.$, $\mathrm{P}=0.001$ ) group, while women with normal pregnancy outcome demonstrate the same pattern but not reach the significant level (Tabl. II).

HSV 2 IgM, as an indicator of current infection was demonstrated in $2 \%$ of the studied population, and was significantly $\left(\mathrm{X}^{2}=9.23\right.$, $\mathrm{P}=0.002)$ higher in women with $\mathrm{BOH}(3.1 \%)$ compared to women with normal pregnancy $(0 \%)$. There was significant $\left(\mathrm{X}^{2}=11.63, \mathrm{P}=0.001\right)$ difference in HSV $2 \mathrm{IgG}$ seroprevalence between pregnant and non pregnant women (Tabl. III).

Both HSV 2 IgG and IgM were significantly varied with age groups, with trends of increasing with older ages $\left(\mathrm{X}^{2}=30.2\right.$, $\mathrm{P}=0.000$ for $\mathrm{IgG} ; \mathrm{X}^{2}=7.93, \mathrm{P}=0.048$ for $\left.\mathrm{IgM}\right)$. HSV $2 \mathrm{IgG}$ seroprevalence was higher in women with age of above 40 $(47.9 \%)$, while lower rate was in the age of $20-29$ years $(24.6 \%)$. HSV 2 IgM was not detected in women with age of less than 20 years, however, the higher seroprevalence rate $(5.5 \%)$ was in women with age of $20-29$ years (Tabl. IV).

\begin{tabular}{|l|l|l|l|}
\hline \multicolumn{2}{|c|}{ Group [Number] } & \multicolumn{2}{c|}{ Number positive [Percent] } \\
\cline { 3 - 4 } \multicolumn{2}{|c|}{ IgM } & \multicolumn{1}{c|}{ IgG } \\
\hline \multirow{5}{*}{ Bad obstetric history } & Pregnant [292] & $8[2.7]$ & $102[34.9]$ \\
\cline { 2 - 4 } & Non- pregnant [255] & $9[3.5]$ & $57[22.4]$ \\
\cline { 2 - 4 } & $X^{2}$ & 0.28 & 10.45 \\
\cline { 2 - 4 } & P value & NS & 0.001 \\
\cline { 2 - 4 } & Total [547] & $17[3.1]$ & $159[29.1]$ \\
\hline Normal pregnancy & Pregnant [140] & $0[0]$ & $42[30]$ \\
\cline { 2 - 4 } & Non- pregnant [151] & $0[0]$ & $50[33.1]$ \\
\cline { 2 - 4 } & $X^{2}$ & - & 2.09 \\
\cline { 2 - 4 } & P value & - & NS \\
\cline { 2 - 4 } & Total [291] & $0[0]$ & $92[31.6]$ \\
\hline Grand total [838] & $17[2]$ & $251[29.9]$ \\
\hline$X^{2}$ BOH versus Normal Pregnancy & 9.23 & 0.59 \\
\hline P value BOH versus Normal Pregnancy & 0.002 & NS \\
\hline
\end{tabular}

Table II. Herpes Simplex virus seroprevalence in women with bad obstetric history.

\begin{tabular}{|c|c|c|}
\hline \multirow[t]{2}{*}{ Group [Number] } & \multicolumn{2}{|c|}{ Number positive [Percent] } \\
\hline & IgM & IgG \\
\hline Pregnant [432] & 8 [1.9] & $152[35.2]$ \\
\hline Non - pregnant [406] & 9 [2.2] & $99[24.4]$ \\
\hline $\mathrm{X}^{2}$ & 0.14 & 11.63 \\
\hline P value & NS & 0.001 \\
\hline
\end{tabular}

Table III. Herpes Simplex virus seroprevalence in pregnant compared to non-pregnant women. 


\begin{tabular}{|c|c|c|c|c|c|c|c|c|}
\hline \multirow{2}{*}{$\begin{array}{l}\text { Age group } \\
\text { in years }\end{array}$} & \multicolumn{4}{|c|}{ IgM Number positiveltotal [\%] } & \multicolumn{4}{|c|}{ IgGNumber positiveltotal [\%] } \\
\hline & Control & Patient & $\mathrm{X} 2$ & Pvalue & Control & Patient & $\mathrm{X} 2$ & PValue \\
\hline $14-19$ & $0 \backslash 47[0]$ & $0 \backslash 45[0]$ & ND & - & $7 \backslash 47[14.9]$ & $14 \backslash 45[31.1]$ & 3.43 & 0.053 \\
\hline $20-29$ & $0 \backslash 126[0]$ & $13 \backslash 240[5.5]$ & 7.1 & 0.008 & $60 \backslash 126[47.6]$ & $59 \backslash 240[24.6]$ & 20.0 & 0.000 \\
\hline $30-39$ & $0 \backslash 86[0]$ & $3 \backslash 214[1.4]$ & 1.2 & NS & $21 \backslash 86[24.4]$ & $63 \backslash 214[29.4]$ & 0.76 & NS \\
\hline $40-48$ & $0 \backslash 32[0]$ & $1 \backslash 48[2.1]$ & 0.67 & NS & $4 \backslash 32[12.5]$ & $23 \backslash 48$ [47.9] & 10.8 & 0.001 \\
\hline$X^{2}$ & ND & 7.93 & & & 28.5 & 30.2 & & \\
\hline P value & - & 0.048 & & & 0.000 & 0.000 & & \\
\hline
\end{tabular}

HSV-2 IgG seroprevalence was significantly different between women with $\mathrm{BOH}$ and control in age groups of 20-29 years $\left(\mathrm{X}^{2}=20, \mathrm{P}=0.000\right)$ and $40-48$ years $\left(\mathrm{X}^{2}=10.8, \mathrm{P}=0.001\right)$. However, IgM seroprevalence was significantly $\left(\mathrm{X}^{2}=7.1\right.$, $\mathrm{P}=0.008$ ) higher in women of 20-29 years of age with $\mathrm{BOH}$ $(5.5 \%)$ than in control group ( $0 \%)$. As shown in Table V, HSV$2 \mathrm{IgM}$ was significantly higher in women with $\mathrm{BOH}$ of age less than 30 years $\left(\mathrm{X}^{2}=4.17, \mathrm{P}=0.044\right)$ and significantly higher in this age group as compared to control $\left(\mathrm{X}^{2}=8.12, \mathrm{P}=0.004\right)$. HSV-2 IgG seroprevalence was significantly higher in control $\left(\mathrm{X}^{2}=8.72, \mathrm{P}=0.003\right)$ as compared to women with $\mathrm{BOH}$ of age $<30$ yrs. However, it was significantly higher in women with $\mathrm{BOH}\left(\mathrm{X}^{2}=5.33, \mathrm{P}=0.021\right)$ as compared to control in women of $>30$ yrs age. Furthermore, Odd ratio indicated a significant association between recent/present infection (positive $\operatorname{IgM}$ ) and younger age $(<30 \mathrm{yrs})(\mathrm{OR}=3.083, \mathrm{P}=0.041)(\mathrm{Tabl}$. V, VI).

The frequency of IgM was higher in urban $(8.6 \%)$ than in rural $(1.1 \%)$ areas with a marginal $\mathrm{p}$ value $(0.055)$. Acute HSV2 infection as demonstrated by IgM detection was higher in housewife $(3.2 \%)$, uneducated $(3.3 \%)$, smoker $(3.4 \%)$, and large size family (3.6\%) as compared to working, educated, non smoker women and small size family, respectively. However, the frequency of acute HSV-2 infection was significantly higher in women with less frequent $\left(6.9 \%, \mathrm{X}^{2}=5.51, \mathrm{p}=0.01\right)$ infection (12) (Tabl. VII). OR confirmed a positive association ( $\mathrm{OR}=3.473$, $\mathrm{p}=0.01$ ) between abortion and recent HSV-2 infection (Tabl VII). Hemoglobin level, animal exposure and presence of congenital anomalies did not show a significant differences and this finding was confirmed by OR calculation (Tabl. VII, VIII).

The pattern of HSV-2 IgG seroprevalence (remote or latent infections) was different from that of acute infection. HSV-2 IgG seroprevalence was significantly higher $\left(\mathrm{X}^{2}=15.667, \mathrm{p}=0.000\right)$ in urban $(34.3 \%)$ than in rural $(17.8 \%)$ areas. OR confirmed the significant association $(\mathrm{OR}=2.41, \mathrm{p}=0.0001)$ between residence and HSV-2 IgG seroprevalence (Tabl. VII, VIII).

HSV 2 IgG was statistically significantly $\left(\mathrm{X}^{2}=4.115, \mathrm{P}=0.03\right)$ higher in working women $(42.2 \%)$ as compared to housewife (27.9\%), however, OR not confirmed an association with mother occupation (OR=1.183, $\mathrm{p}=\mathrm{NS})$ (Tabl. VII, VIII).

HSV-2 IgG seroprevalence was significantly lower $\left(\mathrm{X}^{2}=5.05\right.$, $\mathrm{p}=0.025)$ in uneducated $(27.1 \%)$ as compared to educated $(38.7 \%)$ women. This differences also confirmed by OR calculation $(\mathrm{OR}=1.7, \mathrm{p}=0.02)$ (Tabl. VII, VIII).

Smoking significantly influence HSV $2 \operatorname{IgG}\left(\mathrm{X}^{2}=19.42, \mathrm{P}=0.000\right)$ seroprevalence and $\mathrm{OR}(\mathrm{OR}=2.465, \mathrm{p}=0.000)$ confirmed this association (Tabl. VI, VII). HSV $2 \mathrm{IgG}$ seroprevalence was higher $(30.4 \%)$ in small size $(\mathrm{CR} \leq 3)$ than that in large size family $(26.1 \%)$, but the difference was not statistically significant $\left(\mathrm{X}^{2}=0.84, \mathrm{p}=\mathrm{NS}\right)$ and such association was confirmed by OR $(\mathrm{OR}=1.237, \mathrm{p}=\mathrm{NS})$ (Tabl. VII, VIII).

HSV-2 IgG was significantly $\left(\mathrm{X}^{2}=13.41, \mathrm{p}=0.000\right)$ higher $(38.7 \%)$ in women exposed to animals as compared to non exposed (23.8\%). This association confirmed by $\mathrm{OR}(\mathrm{OR}=2.018$, $\mathrm{p}=0.0002$ ) calculation. However, hemoglobin level, number of abortion, and congenital anomalies did not show any association with HSV-2 IgG prevalence. Pregnancy presence with HSV latent infection was a risk factor for development of $\mathrm{BOH}$ $(\mathrm{OR}=1.683, \mathrm{p}=0.0007)$ in women with latent HSV-2 infections, while not a risk factor in acute infection $(\mathrm{OR}=1.202, \mathrm{p}=>0.05)$ (Tabl. VIII).

\begin{tabular}{|c|c|c|c|c|c|c|c|c|c|c|}
\hline \multirow[t]{2}{*}{ Ageinyears } & \multicolumn{2}{|c|}{ Total No. } & \multicolumn{4}{|c|}{ IgM Number positive [\%] } & \multicolumn{4}{|c|}{ IgG Number positive[\%] } \\
\hline & Control & Patient & Control & Patient & $\mathbf{X}^{2}$ & $\mathbf{P}$ & Control & Patient & $\mathbf{X}^{2}$ & $\mathbf{P}$ \\
\hline $1-29$ & 173 & 285 & $0[0]$ & $13[4.6]$ & 8.12 & 0.004 & $67[38.7]$ & $73[25.6]$ & 8.72 & 0.003 \\
\hline $30-48$ & 118 & 262 & $0[0]$ & $4[1.5]$ & 1.82 & NS & $25[21.2]$ & $86[30.5]$ & 5.33 & 0.021 \\
\hline $\mathrm{X}^{2}$ & & & ND & 4.17 & & & 9.98 & 3.44 & & \\
\hline $\mathrm{P}$ & & & - & 0.044 & & & 0.002 & 0.06 & & \\
\hline
\end{tabular}

Table V. Frequency of HSV -2 according to age of $<30$ and above. 


\begin{tabular}{|l|l|l|}
\hline \multicolumn{1}{|c|}{ Variable } & \multicolumn{1}{c|}{ Odd ratio [95\% Confidence interval] } & \multicolumn{1}{c|}{ P value } \\
\hline HSV 2 IgM & $3.083[0.992-9.577]$ & 0.041 \\
\hline HSV 2 IgG & $1.419[0.979-2.055]$ & NS \\
\hline
\end{tabular}

Table VI. Odd ratio of TORCH agents in regards to age of women lower than 30 years.

\begin{tabular}{|c|c|c|c|}
\hline \multirow[t]{2}{*}{ Variable } & \multirow[t]{2}{*}{ [Number] } & \multicolumn{2}{|c|}{ Number positive [Percent] } \\
\hline & & IgM & IgG \\
\hline \multirow[t]{4}{*}{ Residence } & Rural [174] & $2[1.1]$ & $31[17.8]$ \\
\hline & Urban [373] & $15[8.6]$ & $128[34.3]$ \\
\hline & $X^{2}$ & 3.25 & 15.667 \\
\hline & P value & 0.055 & 0.000 \\
\hline \multirow[t]{4}{*}{ Occupation } & House wife [502] & $16[3.2]$ & 140 [27.9] \\
\hline & Working [45] & $1[2.2]$ & 19 [42.2] \\
\hline & $X^{2}$ & 0.128 & 4.115 \\
\hline & P value & NS & 0.03 \\
\hline \multirow[t]{4}{*}{ Education } & Uneducated [454] & $15[3.3]$ & $123[27.1]$ \\
\hline & Educated [93] & $2[2.2]$ & $36[38.7]$ \\
\hline & $\mathrm{X}^{2}$ & 0.341 & 5.05 \\
\hline & P value & NS & 0.025 \\
\hline \multirow[t]{4}{*}{ Smoking } & Present [327] & $11[3.4]$ & $118[36.1]$ \\
\hline & No smoking [220] & $6[2.7]$ & $41[18.6]$ \\
\hline & $X^{2}$ & 0.17 & 19.42 \\
\hline & $\mathrm{P}$ value & NS & 0.000 \\
\hline \multirow[t]{4}{*}{ Crowding Index } & $\leq 3[478]$ & $11[2.9]$ & $116[30.4]$ \\
\hline & $3.1-8[60]$ & $6[3.6]$ & $43[26.1]$ \\
\hline & $X^{2}$ & 0.04 & 0.84 \\
\hline & PS value & NS & NS \\
\hline \multirow[t]{4}{*}{ Haemoglobin } & $<11[151]$ & $3[2]$ & $36[23.8]$ \\
\hline & $11-19[396]$ & $14[3.5]$ & $123[31.1]$ \\
\hline & $\mathrm{X}^{2}$ & 0.43 & 2.42 \\
\hline & P value & NS & NS \\
\hline \multirow[t]{4}{*}{ Animal exposure } & Present [194] & $5[2.6]$ & $75[38.7]$ \\
\hline & Absent [353] & $12[3.4]$ & 84 [23.8] \\
\hline & $\mathrm{X}^{2}$ & 0.28 & 13.41 \\
\hline & P value & NS & 0.000 \\
\hline \multirow[t]{4}{*}{ Abortion } & $1-2[116]$ & $8[6.9]$ & $31[26.7]$ \\
\hline & $3-8[431]$ & $9[2.1]$ & $128[29.7]$ \\
\hline & $\mathrm{X}^{2}$ & 5.51 & 0.26 \\
\hline & P value & 0.01 & NS \\
\hline \multirow[t]{4}{*}{ Congenital anomalies } & Absent [498] & $16[3.2]$ & $146[29.3]$ \\
\hline & Present [49] & $1[2.1]$ & 13 [26.53] \\
\hline & $X^{2}$ & 0.204 & 0.168 \\
\hline & P value & NS & NS \\
\hline
\end{tabular}




\begin{tabular}{|c|c|c|c|}
\hline Organism & Variable & Odd ratio [95\% Confidence interval] & P value \\
\hline \multirow[t]{2}{*}{ Residence } & $\operatorname{IgM}$ & $0.277[0.063-1.287]$ & NS \\
\hline & $\operatorname{IgG}$ & $2.410[1.547-3.754]$ & 0.0001 \\
\hline \multirow[t]{2}{*}{ Occupation } & $\operatorname{IgM}$ & $1.448[0.187-11.182]$ & NS \\
\hline & IgG & $1.183[0.628-2.228]$ & NS \\
\hline \multirow[t]{2}{*}{ Education } & $\operatorname{IgM}$ & $0.643[0.115-2.862]$ & NS \\
\hline & IgG & $1.700[1.100-2.700]$ & 0.02 \\
\hline \multirow[t]{2}{*}{ Crowding index } & $\operatorname{IgM}$ & $0.786[0.286-1.865]$ & NS \\
\hline & IgG & $1.237[0.821-1.865]$ & NS \\
\hline \multirow[t]{2}{*}{ Smoking } & $\operatorname{IgM}$ & $0.805[0.293-2.211]$ & NS \\
\hline & IgG & $2.465[1.640-3.705]$ & 0.000 \\
\hline \multirow[t]{2}{*}{ Haemoglobin } & $\operatorname{IgM}$ & $0.553[0.157-1.953]$ & NS \\
\hline & IgG & $0.695[0.452-1.069]$ & NS \\
\hline \multirow[t]{2}{*}{ Animal exposure } & $\operatorname{IgM}$ & $0.752[0.261-2.166]$ & NS \\
\hline & IgG & $2.018[1.382-2.948]$ & 0.0002 \\
\hline \multirow[t]{2}{*}{ Abortion } & $\operatorname{IgM}$ & $3.473[1.309-9.123]$ & 0.01 \\
\hline & IgG & $0.863[0.545-1.368]$ & NS \\
\hline \multirow{2}{*}{$\begin{array}{l}\text { Congenital anoma- } \\
\text { lies }\end{array}$} & $\operatorname{IgM}$ & $1.593[0.207-12.278]$ & NS \\
\hline & $\operatorname{IgG}$ & $1.149[0.592-2.229]$ & NS \\
\hline \multirow[t]{2}{*}{ Pregnancy } & $\operatorname{IgM}$ & $1.202[0.459-3.145]$ & NS \\
\hline & IgG & $1.683[1.246-2.274]$ & 0.0007 \\
\hline
\end{tabular}

\section{Discussion}

Infection with herpes simplex is one of the most common sexually transmitted infections. Because the infection is common in women of reproductive age it can be contracted and transmitted to the fetus during pregnancy and the newborn $[15,19]$. Herpes simplex virus is an important cause of neonatal infection, which can lead to death or long-term disabilities. Rarely in the uterus, it occurs frequently during the transmission delivery [24]. The greatest risk of transmission to the fetus and the newborn occurs in case of an initial maternal infection contracted in the second half of pregnancy. However, the transmission risk of maternal-fetal-neonatal herpes simplex can be decreased by performing a treatment with antiviral drugs or delivery by caesarean section [24]. Different geographical areas and studied populations reported in literature indicated a different trends and patterns [25].

In the present study, an overall HSV IgG seroprevalence of $29.9 \%$ was found among women, and there was no significant difference between women with $\mathrm{BOH}(29.1 \%)$ as compared to women with normal pregnancy $(31.6 \%)$. However, there was a significant difference $\left(\mathrm{X}^{2}=11.63, \mathrm{p}=0.001\right)$ in seroprevalence between pregnant $(35.2 \%)$ and non pregnant $(24.4 \%)$ women. The present study seroprevalence was significantly $\left(\mathrm{X}^{2}=5.2\right.$, $\mathrm{p}=0.022)$ higher $(29.9 \%)$ to that reported in a recent study in women $(24.2 \%)$ from Kirkuk population [15]. This variation could be due that sample size in the present study was larger than the previously reported one.

This study HSV 2 seroprevalence (35.2\%) in pregnant women was higher to that reported for Italy (7.6-8.4\%) [24], China (10.8\%) [26], Indonesia (9.9\%) [27], Bangladesh (9.91\%)
[28], and UK (10.4\%) [29], Tanzania (20.7\%) [30], Australia (30\%) [31], USA (22\%) [32], Switzerland (21.2\%) [33], Canada (17.3\%) [34], Senegal (22\%) [35], Belgium (18.2\%) [36], China (23.5\%) [37], and Korea (17\%) [38], Turkey (4.4\%-5\%) [39,40], Kashmir (7.5\%) [41], India (8.7\%) [42], Croatia (6.8\%) [43]. In contrast to our study, a much higher HSV 2 seroprevalence has been reported from Zimbabwe (51.1\%) [44], Germany $(82 \%)$ [45], Turkey (63.1\%) [46], and Iran (43.75\%) [47].

In women with BOH, our HSV2 IgG seroprevalence (29.1\%) was lower to that reported for India (33.58\%) [48] and Nepal (33.3\%) [49]. However, it was higher to that reported for India (16.8$18.6 \%$ ) [50,51]. Furthermore, the seroprevalence was much lower to that reported for Waset (60.6\%), Iraq [14] in women with spontaneous abortion. In pregnant women, this study HSV IgG seroprevalence was higher to that reported for Saudi Arabia (6.5\%-27.1\%) [21,23,52], Qatar (26.3\%) [22], Babylon, Iraq $(22.2 \%)$ [20]. However, it was lower to that reported for Syria $(52 \%)$ [53]. The HSV 2 seroepidemiology in women with BOH as this study indicated was lower $(29.1 \%)$ to a recently reported study $(34.5 \%)$ from the same geographical area [15]. However, the difference was not statistically significant $\left(\mathrm{X}^{2}=2.36, \mathrm{p}\right.$ $>0.05)$. In addition, in $\mathrm{BOH}$ women, HSV-2 seroprevalence was significantly higher $\left(\mathrm{X}^{2}=10.45, \mathrm{p}=0.001\right)$ in $\mathrm{BOH}$ pregnant $(34.9 \%)$ than that in $\mathrm{BOH}$ non pregnant $(22.4 \%)$ women. This pattern of seroprevalence was inverse to that reported recently for Kirkuk in which the seroprevalence rate was higher in non pregnant $\mathrm{BOH}$ women [15]. This variation was due to influence of sample size which is more in this study. The pregnancy was a risk factor $(\mathrm{OR}=1.683, \mathrm{p}=0.0007)$ for development on $\mathrm{BOH}$ in women. 
This could be due to that pregnancy may activate the latent HSV-2 infection and subsequently lead to foetal infection. The activation could be influence by hormonal changes during pregnancy which may affect systemic and mainly local immunity or increased body mass index due to fluid retention.

The HSV 2 IgG seroepidemiology varies between different countries, and between groups of individuals included in the studies reported. For example, studies performed in Iraq (11.1-60.6\%), Saudi Arabia (6.5-27.1\%), and Turkey (4.4\%$63.1 \%$ ), demonstrated a wide range of seroprevalence $[15,19]$. These variations may be attributed to various sexual behavior, number of previous pregnancies, duration of sexual activity, residence, education, occupation and socioeconomic status, sample size, sampling method, race, and sexual behavior of the studied population $[41,42,52,54-56]$. Comparison of the HSV2 seroprevalence in the present study with the mean of that reported for Iraq and global (Tabl. IX) indicated no significant differences $\left(\mathrm{X}^{2}=2.01, \mathrm{p}>0.05\right)$. In addition, bivariate analysis indicated no significant difference in seroprevalence between the present study and that reported recently for $\operatorname{Kirkuk}\left(\mathrm{X}^{2}=2.36\right.$, $\mathrm{p}>0.05)$; present study and mean rate of seroprevalence with the mean of previously reported Iraqi studies $\left(X^{2}=1.45, \mathrm{p}>0.05\right)$; and present versus global studies $\left(X^{2}=0.025, p>0.05\right)$.

HSV-2 IgG Seropositivity in the present study was found to be not significantly associated with history of previous abortion $\left(\mathrm{X}^{2}=0.59, \mathrm{P}=\mathrm{NS}\right)$, a finding not agreed with that reported by others $[15,55,57]$.

However, HSV-2 IgG seroprevalence was more (in women with repeated abortion of $\geq 3$, indication that seroprevalence rate increased with increased number of abortion, a phenomenon could be related to the virulence of the latent virus that may be affected by treatment used for abortion. In contrast, HSV-2 IgM seroprevalence was significantly more in women with $\mathrm{BOH}$ $\left(\mathrm{X}^{2}=9.23, \mathrm{p}=0.002\right)$ as compared to control, in addition, IgM seroprevalence rate significantly $\left(\mathrm{X}^{2}=5.51, \mathrm{p}=0.01\right)$ associated with number of repeated abortion. Furthermore, odd ratio confirmed the association $(\mathrm{OR}=3.473, \mathrm{p}=0.01)$ between recent infection and development of $\mathrm{BOH}$ in women.

In our study, the HSV 2 IgG seroprevalence was more in the older age (40-48 yrs) group (47.9\%), and lower $(24.6 \%)$ in women with age of 20-29 years. In addition, the seroprevalence was higher in women with $\mathrm{BOH}$ of $\geq 30$ years, while the pattern reversed in control group. There was a significant variation $\left(\mathrm{X}^{2}=30.2, \mathrm{P}=0.000\right)$ in HSV $2 \mathrm{IgG}$ seroprevalence between age groups. These findings are comparable to studies reported for other geographical areas [31,36,41,46,52,54-56]. The HSV-2 $\operatorname{IgM}$ seroprevalence was significantly higher $\left(\mathrm{X}^{2}=4.17, \mathrm{p}=0.044\right)$ in women with BOH of 14-19 years of age, OR confirmed such association.

Residence seems to influence HSV 2 seroprevalence as this study demonstrated a significant differences between rural $(17.8 \%)$ and urban (34.3\%) areas. OR confirmed an association between residence and HSV 2 seroprevalence. This findings were not agreed to that reported by others $[15,41]$, however, it was consistent with that reported by Chawla et al [58]. Acute HSV -2 infections also was more in urban areas than in rural, but such difference not reach a significant level. The higher primary infection and seroprevalence may be attributed to sexual behavior in urban areas which is more complicated than in rural areas.

HSV 2 IgG seroprevalence was significantly $\left(\mathrm{X}^{2}=4.11, \mathrm{P}=0.03\right)$ higher in working women (42.2\%) as compared to housewife $(27.9 \%)$ women, however, OR not confirm such association. This findings agreed to that reported by others [40,41,42,46], and a recent one for Kirkuk [15] while one study from Saudi Arabia [52] reported an association, but when the data grouped as we do, no such significant association was achieved.

HSV 2 IgG seroprevalence was significantly $\left(\mathrm{X}^{2}=5.05, \mathrm{P}=0.025\right)$ varies according to women education levels in our study and this association was confirmed by $\mathrm{OR}$ using bivariate analysis $(\mathrm{OR}=$ 1.7, $\mathrm{P}=0.02$ ). This finding agreed to that reported for Kirkuk population [15]. The seroprevalence was steady increased with education, same to that reported by Chawla et al [58] and $\mathrm{Xu}$ et al [59], while other studies show high seroprevalence in less educated women $[52,54,60]$. However, Biswas et al [42] reported higher incidence in women with secondary school education. Page et al [61], showed the highest prevalence of HSV 2 in women with the lowest education level residing in the highest socioeconomic status area. Rathore et al [41] and Agabi et al [62] not found a significant association between HSV seroprevalence and education levels.

\begin{tabular}{|c|c|c|}
\hline \multicolumn{2}{|l|}{ Study } & Value or rate \\
\hline \multicolumn{2}{|l|}{ Present study } & $29.1 \%$ \\
\hline \multicolumn{2}{|l|}{ Kirkuk study } & $34.2 \%$ \\
\hline \multicolumn{2}{|l|}{ Iraqi studies } & $36.9 \%$ \\
\hline \multicolumn{2}{|l|}{ Global studies } & $28.49 \%$ \\
\hline \multicolumn{2}{|l|}{$\mathbf{X}^{2}$} & 2.01 \\
\hline \multicolumn{2}{|l|}{ P value } & NS \\
\hline \multirow[t]{2}{*}{ Present versus Kirkuk study } & $\mathbf{X}^{2}$ & 2.36 \\
\hline & P value & NS \\
\hline \multirow[t]{2}{*}{ Present versus Iraqi } & $\mathbf{X}^{2}$ & 1.45 \\
\hline & P value & NS \\
\hline \multirow[t]{2}{*}{ Present versus Global studies } & $\mathbf{X}^{2}$ & 0.025 \\
\hline & P value & NS \\
\hline
\end{tabular}

Table IX. Comparison of HSV-2 serprevalence rate with other studies. 
In this study, HSV IgG seroprevalence was higher in small size families (crowding index) as compared to large size families and this association was not confirmed by OR calculation. However, Aljumaili et al [15] suggest significant association between small family size and HSV infection. HSV infection is increased with the increase in sexual activity and thus small size families may provide comfortable environment that encourage sex performance. In addition, young women receiving family planning services are at risk for herpes simplex virus type 2 (HSV-2) infection [63].

The literature indicated a paradox in association between HSV 2 seropositivity and lower income and this could be due to differences in risk behavior among the different income groups [15]. It was seen in a study performed for India [42], that majority of Muslims subjects $(84.9 \% ; 0 / 106)$ were from low income group. It was also observed that Muslims subjects had the lowest HSV 2 seroprevalence (3.8\%) compared to Hindu (5.8\%) and Christians (12.6\%), which may explain that disparity. The suggested risk factors that lead to high HSV 2 seropositivity in developed and some undeveloped countries are not applicable in our society due to religious and social reasons [15].Thus other risk factors are to be speculated in our society, one of these is the male circumcision, as it lowers the prevalence of HSV 2 [64]. Recently reported study [41], higher HSV 2 seroprevalence was found among Christians versus Muslims and this differences in prevalence with religions, may be due to practice of male circumcision at infancy or early childhood by the spouses of the pregnant women among Muslims.

Low socioeconomic status observed in some studies to be associated with HSV 2 seroprevalence [41,42,56,58,61]. However, Germany as a country with high socioeconomic status, the HSV 2 seroprevalence was $82 \%$ in pregnant women, while the corresponding value in Arab countries ranged from $6.5 \%$ to $27.1 \%$. Thus Islamic legislation concerning faithful family relations and personal hygiene are an important factors that reduce HSV 2 infection [15].

Smoking was associated with significantly higher $\left(X^{2}=19.42\right.$, $\mathrm{p}=0.000)$ HSV-2 seroprevalence $(36.1 \%)$ and this high frequency in smoking women was confirmed by $\mathrm{OR}(\mathrm{OR}=2.465$, $\mathrm{p}=0.000$ ). Hemoglobin level was not demonstrated a significant association with development of $\mathrm{BOH}$ in women. However, HSV-2 seroprevalence was significantly higher $\left(X^{2}=13.41\right.$, $\mathrm{p}=0.000$ ) in women with history of animal exposure and this association confirmed by $\mathrm{OR}(\mathrm{OR}=2.018, \mathrm{p}=0.0002)$.

HSV 2 IgM seroprevalence was $2 \%$ indicating that current infection of $2 \%$ in our study population, and it was significantly higher $\left(\mathrm{X}^{2}=9.23, \mathrm{P}=0.002\right)$ in women with $\mathrm{BOH}(3.5 \%)$ as compared to women with normal pregnancy $(0 \%)$, and about the same in pregnant and non pregnant women. This finding agreed to that reported recent for women in Kirkuk [15]. Our HSV IgM (1.9\%) seroprevalence in pregnant women was higher than that reported for Turkey (0\%) [39], Saudi Arabia (0.5\%) [21], Croatia (1.2\%) [43], and Bangladesh (1.8\%) [28]. Higher seroprevalence was reported for Babylon, Iraq (28.9\%) [20], Turkey (13.8\%) [46], Qatar (7.6\%) [22] and Kirkuk (3.1\%) [15]. In women with $\mathrm{BOH}$, HSV IgM seroprevalence (3.1\%) was lower than that reported for India $[48,50,68,69]$, Baghdad, Iraq [16], Waset, Iraq [14], Mosul, Iraq [17], Kirkuk, Iraq [15]. Thus current infection with HSV 2 was lower to that reported in other Iraqi Governorates including Kirkuk [15].

The present study shows a significant variation in current HSV 2 infection between age groups $\left(\mathrm{X}^{2}=7.93, \mathrm{P}=0.048\right)$, the highest incidence in women with age of 20-29 years (5.5\%) old, while the lowest rate in women of $<19$ years old. Using Bivariate analysis, OR confirmed an association between HSV 2 current infection and age of $<30$ or $>30$ years old $(O R=3.083, p=0.041)$. Furthermore, residence, family size, smoking, hemoglobin level, animal exposure, congenital anomalies and occupation were not show association with HSV-2 IgM seroprevalence. However, current infection of HSV 2 was significantly higher in women with 1 to 2 abortion and OR confirmed such association $(\mathrm{OR}=3.473, \mathrm{p}=0.01)$.

\section{Conclusion}

The present study indicated a significant association between HSV 2 IgG and IgM and bad obstetric history. The overall HSV 2 seroprevalence in our study population was $29.9 \%$, with no significant difference between women with $\mathrm{BOH}$ and women with normal pregnancy. Significant association was found between HSV 2 seroprevalence and urban residence, education levels, smoking, and animal exposure. However, HSV 2 seroprevalence was different due to occupation, family size, hemoglobin level, abortion number, congenital anomalies, and age of $<30$ years, but OR not confirmed significant association. Furthermore, presence of pregnancy with HSV-2 IgG was a risk factor for development of $\mathrm{BOH}$.

\section{REFERENCES}

1. Johnson P, Barnes R, Hart C, Francis W. Determinants of immunological responsiveness in recurrent spontaneous abortion. Transpl. 1994;38:280-4.

2. Howard M, Sellors JW, Jang D1. Regional distribution of antibodies to herpes simplex virus type 1 (HSV-1) and HSV-2 in men and women in Ontario, Canada. J Clin Microbiol. 2003;41:84-9.

3. Alsamarai AGM. Type incidence of HSV in clinical isolates from patients with herpes genitalis. Ann Saudi Med. 1990;10:156-60.

4. Corey L, Adams HG, Brown ZA, Homes KK. Genital herpes simplex virus infections: clinical manifestations, course, and complications, Ann Intern Med. 1983;98:958.

5. Kulhanjian JA, Soroush V, Au DS, Bronzan RN, Yasukawa LL, Weylman LE, et al. Identification of women at unsuspected risk of primary infection with herpes simplex virus type 2 during pregnancy. N Engl J Med. 1992;326:916.

6. Frenkel LM, Garratty EM, Shen JP, Wheeler N, Clark O, Bryson YJ. Clinical reactivation of herpes simplex virus type 2 infection in seropositive pregnant women with no history of genital herpes. Ann Intern Med. 1993;118:414.

7. Jabar AA, Al-Samarai AM, Al-Amar NS. HLA antigens associated with susceptibility to HSV infection. Disease Marker [USA]. 1991;9;281-7.

8. Kimberlin DW, Whitley RJ. Neonatal herpes: what have we learned. Semin Pediatr Infect Dis. 2005;16:7-16.

9. Brown ZA, Selke S, Zeh J, Kopelman J, Maslow A, Ashley RL, et al. The acquisition of herpes simplex virus during pregnancy. N Engl J Med. 1997;337:509-15.

10. Brown Z. Preventing herpes simplex virus transmission to the neonate. Herpes. 2004;3:175A-86A.

11. Whitley RJ. Herpes Simplex Viruses. In: Knipe DM, Howley PM, Griffin DE, et al eds. Fields Virology. 4th ed. Vol 2. New York: Lippincott. 2001; 2461-509.

12. Al-Hasani AM, Barton IG, AL-Omer LS, Kinghorn GR Potter CW. Susceptibility of HSV strains from patients with genital herpes treated with various formulations of ACV. J Antimicrob Chemother. 1986;18:113-20S. 
13. Samarai AM, Shareef AA, Kinghorn GR, Potter CW. Sequential genital infections with HSV type $1 \& 2$. Genito- Urinary Med [England]. 1989;65:39-41.

14. Jasim M, Majeed HA, Ali AI. Performance of Serological Diagnosis of TORCH Agents in Aborted versus non aborted Women of Waset province in Iraq. Tikrit Med J. 2011;17:141-7.

15. Aljumaili ZK, Alsamarai AGM, Najem WS. Seroprevalence of herpes simplex type 2 (HSV-2) in women with bad obstetric history. Am J Derm Vener. 2013;2:31-8.

16. Abdul Mohymen N, Hussien A, Hassan FK. Association between TORCH agents and recurrent spontaneous abortion. Iraqi J Med Sci. 2009;7:40-6.

17. AL-Taie AAD. Serological Study For TORCH Infections In Women With High Delivery Risk Factors In Mosul. Tikrit J Pure Scienc. 2010;15:193-8

18. Aljumaili ZK, Alsamarai AGM, Najem WS. Seroepidemiological Study of Toxoplasma, Rubella, Cytomegalovirus and Herpes Simplex in Women with Bad Obstetric History. Am J Dermatol Venereol. 2013;2:31-8.

19. Alsamarai AGM, Ajumaili ZK. Seroepidemiology of Toxoplasma, Rubella, Cytomegalovirus and Herpes Simplex Virus -2 in Women with Bad Obstetric History. PART II. Cytomegalovirus and Herpes Simplex Virus Infections. Our Dermatol Online. 2013;4:536-44.

20. Al-Marzoqi AHM, Kadhim RA, Aljanabi DKF, Hussein HJ, Al Tae ZM. Seroprevalence study of IgG and IgM Antibodies to Toxoplasma, Rubella, Cytomegalovirus, Chlamydia trachomatis and Herpes simplex II in Pregnancy women in Babylon Province. J Biol Agricultur Health. 2012;2:159-64.

21. Alzahranil AJ, Obeid OE, Almulhim AA, Awari B, Taha A, et al. Analysis of Herpes Simplex 1 and 2 IgG and IgM Antibodies in Pregnant Women and their Neonates. Saudi J Obstet Gynaecol. 2005;5:53-7.

22. Abu-Madi MA, Behnke JM, Dabritz HA. Toxoplasma gondii seropositivity and co-infection with TORCH pathogens in high-risk patients from Qatar. Am J Trop Med Hyg. 2010;82;626-33.

23. Ghazi, HO, Telmesani, AM, Mahomed, MF. Torch agents in pregnant Saudi women. Med Princ Pract. 2002;4:180-90.

24. Straface G, Selmin A, Zanardo V, Santis MD, Ercoli A, Scambia G. Herpes Simplex Virus Infection in Pregnancy. Infect Dis Obstet Gynecol. 2012;2012:385697.

25. Smith JS, Robinson NJ. Age-specific prevalence of infection with herpes simplex virus types 2 and 1: a global review. J Infect Dis. 2002;186:S3-28.

26. Chen X, Yin Y, Chen L, Yu Y, Wei W, Thuy NTT, et al. Herpes simplex virus 2 infection in women attending an antenatal clinic in Fuzhou, China. Sex Transmit Infect. 2007;83:369-70.

27. Joesoef MR, Sumampouw H, Linnan M, Schmid S, Idajadi A, Louis ME et al. Sexually transmitted diseases in pregnant women in Surabaya, Indonesia. Am J Obstet Gynecol. 1996;174:115-9.

28. Nabi SN, Wasey A, Haider KMTS, Khan AA, Hoque MM. Seroprevalen of TORCH antibody in pregnant women. J Arm Forces Med Colle. 2012;8:35-9.

29. Ades AE, Peckham CS, Dale GE, Best JM, Jeansson S. Prevalence of antibodies to herpes simplex virus types 1 and 2 in pregnant women, and estimated rates of infection. J Epidemiol Community Health. 1989;43:53-60.

30. Yahya-Malima KI, Evjen-Olsen B, Matee MI, Fylkesnes K, Haarr L. HIV-1, HSV-2 and syphilis among pregnant women in a rural area of Tanzania: prevalence and risk factors. BMC Infect Dis. 2008;8:e75.

31. Haddow LJ, Sullivan EA, Taylor J, Abel M, Cunningham AL, Tabrizi S. Herpes simplex virus type 2 (HSV-2) infection in women attending an antenatal clinic in the South Pacific island nation of Vanuatu. Sex Transmit Dis. 2007;34:258-61.

32. Xu F, Markowitz LE, Gottlieb SL, Berman SM. Seroprevalence of herpes simplex virus types 1 and 2 in pregnant women in the United States. Am J Obstet Gynecol. 2007;196:43.e1-6.
33. Kucera P, Gerber S, Marques-Vidal P, Meylan PR. Seroepidemiology of herpes simplex virus type 1 and 2 in pregnant women in Switzerland: an obstetric clinic based study. Eur J Obstet Gynecol Reprod Biol. 2012;160:13-7.

34. Patrick DM, Dawar M, Cook DA, Krajden M, Ng HC, Rekart ML. Antenatal seroprevalence of herpes simplex virus type 2 (HSV2) in Canadian women: HSV-2 prevalence increases throughout the reproductive years. Sex Transm Dis. 2001;28:424-8.

35. Diawara S, Toure Kane C, Legoff J, Gaye AG, Mboup S, Bélec L. Low seroprevalence of herpes simplex virus type 2 among pregnant women in Senegal. Int J STD AIDS. 2008;19:159-60.

36. Bodéus M, Laffineur K, Kabamba-Mukadi B, Hubinont C, Bernard P, Goubau P. Seroepidemiology of herpes simplex type 2 in pregnant women in Belgium. Sex Transm Dis. 2004;31:297-300. 37. Li JM, Chen YR, Li XT, Xu WC. Screening of Herpes simplex virus 2 infection among pregnant women in southern China. J Dermatol. 2011;38:120-4.

38. Kim D, Chang HS, Hwang KJ. Herpes Simplex Virus 2 Infection Rate and Necessity of Screening during Pregnancy: A Clinical and Sero-epidemiologic Study. Yonsei Med J. 2010;53:401-7.

39. Ozdemir M, Kalem F, Feyzioglu B, Bysal B. Investigation of viral pathogen during pregnancyin a city region in Turkey. Anatol $\mathrm{J}$ Clin Invest. 2011;5:78-81.

40. Dolar N, Serdaroglu S, Yilmaz G, Ergin S. Seroprevalence of herpes simplex virus type 1 and type 2 in Turkey. J Eur Acad Dermatol Venereol. 2006;20:1232-6.

41. Rathore S, Jamwal A, Gupta V. Herpes simplex virus type 2: Seroprevalence in antenatal women. Indian J STD \& AIDS. 2010;31:11-5.

42. Biswas D, Borkakoty B, Mahanta J, Walia K, Saikia L, Akoijam BS. Seroprevalence and risk factors of herpes simplex virus type-2 infection among pregnant women in Northeast India. BMC Infectious Diseases. 2011;11:325-33.

43. Vilibik-Cavlek T, Ljubin-Sternak S, Ban M, Kolaric B, Sviben M, Mlinaric-Galinovic G. Seroprevalence of TORCH infections in women of childbearing age in Croatia. J Matern Fetal Neonatal Med. 2011;24:280-3.

44. Kurewa NE, Mapingure MP, Munjoma MW, Chirenje MZ, Rusakaniko S, Stray-Pedersen B. The burden and risk factors of sexually transmitted infections and reproductive tract infections among pregnant women in Zimbabwe. BMC Infect Dis. 2010;10:e127.

45. Sauerbrei A, Schmitt S, Scheper T, Brandstudt A, Saschenbrecker S, Motz M, Soutschek E, Wutzler P. Seroprevalence of herpes simplex virus type 1 and type 2 in Thuringia, Germany, 1999 to 2006. Euro Surveill. 16(44):pii=20005, 2011.. Available online: http://www. eurosurveillance.org/ViewArticle.aspx? ArticleId=20005

46. Duran N, Fugen Y, Cuneyt E, Fatih K. Asymptomatic herpes simplex virus type 2 (HSV-2) infection among pregnant women in Turkey. Indian J Med Res. 2004;120:106-10.

47. Shahraki AD, Moghim S, Akbari P. A survey on herpes simplex type 2 antibody among pregnant women in Isfahan, Iran. J Res Med Sci. 2010;15:243.

48. Turbadkar D, Mathur M, Rele M. Seroprevalence of TORCH infection in bad obstetric history. Indian J Med Microbiol. 2003;21:108-11.

49. Kumari N, Morris N, Dutta R. Is screening of TORCH worthwhile in women with bad obstetric history: an observation from eastern Nepal. J Health Pop Nutr. 2011;29:77-80.

50. Haider M, Rizvi M, Khan N, Malik A. Serological study of herpes virus infection in female patients with bad obstetric history. Biol Med. 2011;3284-90.

51. Sadik MS, Fatima H, Jamil K, Patil C. Study of TORCH profile in patients with bad obstetric history. Biol Med. 2012;4:95-101. 
52. Obeid OE. Prevalence of herpes simplex virus types 1 and 2 and associated sociodemographic variables in pregnant women attending King Fahd Hospital of the university. J Fam Commun Med. 2007;14:3-7

53. Barah F. Prevalence of herpes simplex types 1 and 2, varicella zoster virus, cytomegalovirus, immunoglobulin $\mathrm{G}$ antibodies among female university students in Syria. Saudi Med J. 2012;33:990-4. 54. Tidemam RL, Taylor J, Marks C, Seifert C, Berry G, Trudinger $\mathrm{B}$, et al. Sexual and demographic risk facrors for herpes simplex type 1 and 2 in women attending an antenatal clinic. Sex Transm Infect. 2001;77:413-5.

55. Breinig MK, Kingsley LA, Armstrong JA, Freemam DJ, Ho M. Epidemiology of genital herpes in Pittsburgh: Serologic, sexual and racial correlates of apparent and inapparent herpes simplex infections. J Infect Dis. 1990;162:299-305.

56. Jennings JM, Louis TA, Ellen JM, Srikrishnan AK, Sivaram S, Mayer K, et al. Geographic prevalence and multilevel determination of community level factors associated with herpes simplex virus type 2 infection in Chennai, India. Am J Epidemiol. 2008;167:1495-503. 57. Frenkel LM, Garraty EM, Shen JP, Wheeler N, Clark O, Bryson YJ. Clinical reactivation of herpes simplex virus type 2 infection in seropositive pregnant women with no history of genital herpes. Ann Intern Med. 1993;118:414-8.

58. Chawla R, Bhalla P, Bhalla K, Sing MM, Garg S. Community based study on seroprevalence of herpes simplex type 2 infection in New Dwlhi. Indian J Med Micrbiol, 2008;26t:34-9.
59. Xu F, Sternberg MR, Gottlieb SL, Berman SM, Markowitz LE, Forhan SE, et al. Serprevalence of herpes simplex virus type 2 among person aged 14-49 years- United States, 2005-2008. MMWR. 2010;59:456-9.

60. Fleming DT, McQuillan GM, Johnson RE, Nahmias AJ, Aral SO, Lee FK, et al. Herpes simplex virus type 2 in the Unites States, 1976-1994. New Eng J Med. 1997;337:1105-11.

61. Page A, Taylor R, Richters J, Shaw J, Taylor J, Cunningham A, et al. Upstairs and downstairs : socioeconomic and gender interactions in herpes virus type 2 seroprevalence in Australia. Sex Transm Dis. 2009;36:344-9.

62. Agabi YA, Banwat EB, Mawak JD, Lar PM, Dashe N, Dashen $\mathrm{MM}$, et al. Seroprevalence of herpes simplex virus type- 2 among patients attending the Sexually Transmitted Infections Clinic in Jos, Nigeria. J Infect Dev Ctries. 2010;4:572-5.

63. Moss NJ, Harper CC, Ahrens K, Scott S, Kao S, Padian N, et al. Predictors of incident herpes simplex virus type 2 infections in young women at risk for unintended pregnancy in San Francisco. BMC Infect Dis. 2007;7:113.

64. Tobian AAR, Serwadda D, Quinn TC, Kigozi G, Gravitt PE, Laeyendecker $\mathrm{O}$, et al. Male circumcision for the prevention of HSV2 and HPV infections and syphilis. N Engl J Med. 2009;360:1298309. 